AperTO - Archivio Istituzionale Open Access dell'Università di Torino

\title{
Autonomic Tone Activity Before the Onset of Atrial Fibrillation
}

\section{This is the author's manuscript}

Original Citation:

Availability:

This version is available http://hdl.handle.net/2318/1624217

since 2017-04-20T15:46:00Z

Published version:

DOI: $10.1111 / j c e .13150$

Terms of use:

Open Access

Anyone can freely access the full text of works made available as "Open Access". Works made available under a Creative Commons license can be used according to the terms and conditions of said license. Use of all other works requires consent of the right holder (author or publisher) if not exempted from copyright protection by the applicable law. 
This is the author's final version of the contribution published as:

Gallo, Cristina; Bocchino, Pier Paolo; Magnano, Massimo; Gaido, Luca; Zema, Domenica; Battaglia, Alberto; Anselmino, Matteo; Gaita, Fiorenzo. Autonomic Tone Activity Before the Onset of Atrial Fibrillation. JOURNAL OF CARDIOVASCULAR ELECTROPHYSIOLOGY. 28 (3) pp: 304-314. DOI: $10.1111 /$ jce. 13150

The publisher's version is available at:

http://onlinelibrary.wiley.com/wol1/doi/10.1111/jce.13150/fullpdf

When citing, please refer to the published version.

Link to this full text:

http://hdl.handle.net/2318/1624217 


\section{Autonomic tone activity before the onset of Atrial Fibrillation}

Cristina Gallo ${ }^{1}$, MD, Pier Paolo Bocchino ${ }^{1}, \mathrm{MD}$, Massimo Magnano ${ }^{1}$, MD, Luca Gaido ${ }^{1}$, MD, Domenica Zema ${ }^{1}, \mathrm{MD}$, Alberto Battaglia ${ }^{1}$, MD, Matteo Anselmino ${ }^{1}, \mathrm{MD} \mathrm{PhD}$, Fiorenzo Gaita $^{1}$, MD Prof.

${ }^{1}$ Division of Cardiology, Department of Medical Sciences, ñCittà della Salute e della Scienzaò Hospital, University of Turin, Italy

\section{Corresponding Author:}

Fiorenzo Gaita, MD Professor

Cardiology Division, Department of Medical Sciences,

ñCittà della Salute e della Scienzaò University of Turin

Corso Bramante 88, 10126 Turin, Italy

Phone: +39-0116335570 Fax: +39-0116335572

Email: fiorenzo.gaita@unito.it

Short title: Autonomic nervous system activity before AF onset 


\begin{abstract}
Introduction: The autonomic nervous system has been proven to play a major role in the onset of atrial fibrillation (AF), along with a predisposing substrate and a specific trigger event usually consisting of a premature supraventricular ectopic beat (SVEB). By means of heart rate variability (HRV) analysis, we investigated the activity of the autonomic nervous system before SVEBs non-triggering and triggering AF.
\end{abstract}

Methods and Results: We evaluated 28 patients with at least one episode of sustained AF (> 30 seconds) recorded during 24-hour Holter monitorings. We performed HRV analysis during the hour preceding $35 \mathrm{AF}$ onsets and compared these results with the HRV values before non-triggering SVEBs with similar prematurity. According to the low frequency (LF)/ high frequency (HF) ratio in the 5 minutes before the onset, AF episodes were classified as either vagal $(\mathrm{LF} / \mathrm{HF}$ ratio < 1.5) or adrenergic $(\mathrm{LF} / \mathrm{HF}$ ratio Ó1.5).

Vagal episodes (16) showed a decrease in LF (from $50.81 \pm 1.67$ to $32.73 \pm 3.54$ ) and an increase in HF (from $36.00 \pm 2.30$ to $54.7 \pm 3.69$ ) throughout the hour preceding the onset. Adrenergic episodes (19) had opposite changes in LF (from $55.4 \pm 4,95$ to $67.51 \pm 5.24$ ) and HF (from $33.78 \pm 5.82$ to $27.96 \pm 3.51$ ) during the same period. No similar trends were observed before the selected non-triggering SVEBs.

Conclusion: Only SVEBs occurring during a phase of hyperactivity of one of the two branches of the autonomic nervous system are able to trigger episodes of AF.

Key Words: atrial fibrillation, heart rate variability, onset mechanism, ectopic activity, autonomic nervous system 


\section{Introduction}

Atrial fibrillation (AF) is the most common arrhythmia encountered in clinical practice. ${ }^{1}$ It affects both life expectancy and quality of life, with considerable morbidity and mortality. ${ }^{1}$ The prevalence of AF has markedly grown in the Western countries throughout the last decades. Prevention and effective treatment of AF are therefore of major importance.

The pathophysiology of AF is still challenging; it is a complex disease with multiple mechanisms involved (triggers and maintaining factors). Nevertheless, it is well-known that three major elements, together known as Coumelôs triangle, are necessary for the onset of atrial arrhythmias: a predisposing substrate, a trigger event and an imbalance of the autonomic nervous system. ${ }^{2}$

An enlarged atrium with electric, contractile and/or structural remodeling is typically the environment on which AF can appear and maintain itself. ${ }^{3}$ A premature beat, usually originating from the pulmonary veins ${ }^{4}$, is often the ectopic trigger promoting the onset of AF; in fact, several studies have shown that the probability of onset of AF relates to the coupling interval (CI) of the ectopic beat, with a shorter CI being associated with a higher probability of AF induction. ${ }^{5,6}$

Moreover, the autonomic nervous system plays an important role in both the initiation and the maintenance of AF. Complex interactions between the two branches of the autonomic nervous system are responsible for both modification of conduction and refractoriness properties of the heart, and influence triggered activity, known to generate atrial fibrillation. ${ }^{7}$ Since 1978 Coumel investigated the role of the autonomic nervous system in the onset of AF using by Holter recordings and identified two types of paroxysmal AF onset, vagal and adrenergic, based on time of onset and variations of the heart rate preceding the episodes. ${ }^{8,9}$ In fact, most episodes of lone paroxysmal AF seem to be vagally-mediated due to increased 
susceptibility to vasovagal cardiovascular response, while in most patients with organic heart diseases the onsets of paroxysmal AF appear sympathetically-mediated. ${ }^{10}$

Autonomic nervous system activity can be indirectly evaluated by analysis of heart rate variability (HRV) parameters on continuous ECG recordings. Several studies have tried to define the changes in HRV occurring before the onset of AF, but conflicting results have been reported. ${ }^{11-14}$

The aim of our study was to analyze HRV and to assess whether there was an alteration of the autonomic tone before the onset of paroxysmal AF.

\section{Methods}

Between April $1^{\text {st }} 2014$ and December $31^{\text {st }} 2015$, more than 2500 Holter monitorings were recorded at our institution. The ARIA recorder (Del Mar Reynolds Medical Inc., Spacelabs Healthcare, Issaquah, WA, USA) with a sampling frequency of 128 Hertz and 8 bit of resolution was used. Recordings were analyzed using Impresario software (Del Mar Reynolds Medical Inc. All patients gave written informed consent for participation in the study, which was approved by the institutional ethic committee and was performed according to the principles of the Declaration of Helsinki.

Holter recordings were eligible for further analysis if the following criteria were met: (1) normal sinus rhythm during at least $70 \%$ of the recording period, (2) onset of one or more episodes of sustained (Ó 30 seconds) AF, (3) presence of at least 1 hour of sinus rhythm before the onset of AF, (4) presence of none or few artifacts in the hour preceding the onset of $\mathrm{AF},(5)$ premature ectopic beats accounting for less than $10 \%$ of the total recording beats, (6) recording lasting more than 18 hour.

The presence and type of structural heart disease was assessed on the basis of medical history, clinical examination and 12-lead resting ECG. 
The selected recordings were analyzed by two experience cardiologists (more than 500 Holters/year) in a double-blind fashion; in case of non-concordance between the two operators the event was referred to a third specialist. All episodes of sustained atrial arrhythmias were manually identified and labeled.

Time of day and duration of each episode of AF were recorded. A triggering supraventricular ectopic beat (SVEB) was searched for at the beginning of each episode and its presence was confirmed if a clear ectopic P-wave was the last beat before the onset of the arrhythmia. The CI of the triggering SVEB and the preceding PP cycle (PC) were measured; the Prematurity Index (PI), defined as the ratio between CI and PC, was calculated. The amount of SVEBs during each hour of recording was registered as well.

The recording was then manually scanned for any isolated spontaneous SVEB not eliciting any arrhythmias but having the same CI as the triggering SVEB; the hour following the end of episodes of AF was excluded from the search. If there was no SVEB with the same CI as the triggering SVEB, the non-triggering SVEB with a shorter and yet most similar CI to the CI of the triggering SVEB was selected. If more than one non-triggering SVEB had an identical CI, the non-triggering SVEB with the PC most similar to the PC of the triggering SVEB was selected.

Heart rate variability (HRV) was used as indicator of autonomic activity in accordance with guidelines for standardization. ${ }^{15}$ The following time periods were selected for HRV analysis in time domain and frequency domain: the whole period of recording; the hour preceding the triggering SVEB divided into eight 5-minute periods: 55 to $60 \mathrm{~min}, 40$ to $45 \mathrm{~min}, 25$ to 30 $\min , 20$ to $25 \mathrm{~min}, 15$ to $20 \mathrm{~min}, 10$ to $15 \mathrm{~min}, 5$ to $10 \mathrm{~min}$ and 0 to $5 \mathrm{~min}$ before the onset of AF; the hour preceding the selected non-triggering SVEB divided into the same 5-min periods. 
The following time-domain HRV parameters were analyzed over the 5-minute periods: the standard deviation of the $\mathrm{NN}$ intervals (SDNN; in $\mathrm{ms}$ ), the root-mean square of differences between successive NN intervals (RMSSD; in ms), the standard deviation of differences between adjacent $\mathrm{NN}$ intervals (SDSD; in $\mathrm{ms}$ ) and the proportion of adjacent $\mathrm{NN}$ intervals differing by more than $50 \mathrm{~ms}(\mathrm{pNN} 50 ; \%)$.

HRV in the frequency domain (fast Fourier transform) was analyzed over the same 5-minute periods, and the following parameters were calculated: very-low-frequency components (VLF; < $0.04 \mathrm{~Hz}$ ), low-frequency components (LF; from 0.04 to $0.15 \mathrm{~Hz}$ ), high-frequency components (HF; from 0.15 to $0.40 \mathrm{~Hz}$ ), very-high-frequency components (VHF; > $0.40 \mathrm{~Hz}$ ) and the ratio of $\mathrm{LF} / \mathrm{HF}$. The $\mathrm{LF}, \mathrm{HF}$ and VHF components were measured in normalized units, which represent the relative value of each power component in proportion to the total power minus the VLF component. The vagal activity is the main contributor to the HF component; conversely, the LF component is thought to be dependent upon either the sympathetic tone alone or a combination of both adrenergic and vagal activities.15 More controversial is the interpretation of the VLF and VHF components, on which no consensus has yet been reached.15

The same HRV parameters of the time and frequency domains were calculated over the 24 hours of recording.

As for Task Force recommendations trigger episodes were defined as vagal if HRV analysis showed a $\mathrm{LF} / \mathrm{HF}$ ratio $<1.5$ in the 5 minutes before the onset of $\mathrm{AF}$, as opposed to the episodes with a LF/HF ratio Ó1.5 which were instead indicated as adrenergic. ${ }^{15}$

\section{Statistical analysis}

All measures are presented as mean \pm standard deviation. Statistical significance of differences between mean values was tested with paired Studentôs $t$-test as appropriate. 
Frequencies were compared using the $G^{2}$ distribution. For the comparison of data obtained at different time intervals, analysis of variance (ANOVA) was used, employing the Bonferroni correction. P-value < 0.05 was considered statistically significant.

\section{Results}

Among the 2500 Holter recordings scanned, 443 were ruled out because of the presence of $\mathrm{AF}$ or atrial flutter throughout all the duration of the recording. 82 recordings contained one or more AF onsets, but 54 did not match the aforementioned inclusion criteria. 28 twenty-fourhour recordings were therefore analyzed including 35 onsets of AF $(1.25 \pm 0.5$ for each recording). The clinical characteristics of the study population are summarized in Table 1. Mean age was $68.3 \pm 10$ years; 19 were males $(68 \%), 9$ had history of coronary disease (32\%), 22 had hypertension (79\%), 8 had previous catheter ablation of AF (29\%) and 1 had history of cerebrovascular ischemia (4\%).

\section{Vagal and adrenergic onsets}

A vagal trigger in $\mathrm{AF}$ onset was detected in 16 episodes (mean $\mathrm{LF} / \mathrm{HF}_{0-5}$ min $=0.60 \pm 0.09$; mean $\left.\mathrm{LF} / \mathrm{HF}_{24 \mathrm{~h}}=1.65 \pm 1.29\right)$, which were classified as group A.

An adrenergic trigger was detected in 19 episodes (mean $\mathrm{LF} / \mathrm{HF}_{0-5}$ min $2.47 \pm 0.46$; mean $\left.\mathrm{LF} / \mathrm{HF}_{24 \mathrm{~h}} 1.21 \pm 0.93\right)$, which were labeled as group B.

Clinical features of group A and group B were not statistically different (Table 2).

Not surprisingly, as we can depict from Figure 1, a higher prevalence of vagal triggered episodes occurred in the post lunch period. We found no difference in duration of the AF episodes in group A compared with group B $(5821 \pm 12800 \mathrm{~s}$ and $5938 \pm 7763 \mathrm{~s}$ respectively, $\mathrm{p}=0.97)$. 
In group A, a triggering SVEB was detected in 15/16 episodes, with a mean CI of $521 \pm 123$ $\mathrm{ms}$, a mean PC of $963 \pm 236 \mathrm{~ms}$ and a mean PI of $0.55 \pm 0.1$. In one vagal onset, a triggering SVEB couldnâ be detected, but the onset was preceded by a pause, due to a sinus node arrest, of 7 seconds and consequent start after a ventricular beat. In group B, a triggering SVEB was detected in all episodes, with a mean CI of $494 \pm 70 \mathrm{~ms}$, a mean PC of $919 \pm 155 \mathrm{~ms}$ and a mean PI of $0.55 \pm 0.1$. Two patients had both vagal and adrenergic onsets of AF during the 24-hour recording. As far as CI, PC and PI are concerned, no statistically significant differences could be found between the two groups ( $\mathrm{p}=0.42, \mathrm{p}=0.52$ and $\mathrm{p}=0.57$ respectively). Figure 2 shows an example of a triggering SVEB and its control non-triggering SVEB with different autonomous nervous system background.

We found no significant difference between the prevalence of SVEBs registered during the hour before AF onset and the mean prevalence of SVEBs per hour recorded throughout the remaining hours of the day ( $97 \pm 180$ vs $97 \pm 180$, $p$ value 0.977$)$.

HRV before triggering SVEBs and non-triggering SVEBs in vagal onsets As for the triggering SVEBs, a progressive significant decrease in LF values was observed between the 40-45 minutes and the 25-30 minutes periods (from $52.22 \pm 3.14$ to $43.52 \pm$ 1.79) and during the last 10 minutes before the onset of $\mathrm{AF}$ (from $41.45 \pm 3.27$ to $32.37 \pm$ 3.54). The lowest value was observed during the 0-5 min period before the AF onset. There was no difference between the $\mathrm{LF}_{55-60 \mathrm{~min}}$ and the $\mathrm{LF}_{24 \mathrm{~h}}(50.81 \pm 1.67$ vs $52.37 \pm 15.14$, $\mathrm{p}=0.69$ ). Instead, decrease was not observed in LF values preceding the non-triggering SVEB and there was no statistically significant difference between the values of $\mathrm{LF}_{0-5}$ min and $\mathrm{LF}_{24 \mathrm{~h}}$ $(45.25 \pm 2.08$ vs $52.37 \pm 15.14, \mathrm{p}=0.08)$. LF values during the 20 minutes before the triggering SVEB were significantly lower than before the non-triggering SVEB (Table 3 and Figure 3$)$, particularly during the $0-5$ minutes period $(32.73 \pm 3.54$ vs $45.25 \pm 2.08, \mathrm{p}<0.001)$. 
A significant increase in HF values was observed between the 55-60 minutes and the 40-45 minutes periods (from $36 \pm 2.3$ to $43.75 \pm 2.78$ ) and between the $25-30$ minutes and the $20-25$ minutes periods (from $44.01 \pm 3.4$ to $51 \pm 4.36$ ). A progressive increase was detected starting 15 minutes before to the $\mathrm{AF}$ onset (from $50.37 \pm 2.18$ to $54.70 \pm 3.69$ ). There was no difference between the $\mathrm{HF}_{55-60 \text { min }}$ and the $\mathrm{HF}_{24 \mathrm{~h}}$ values (36 \pm 2.3 vs $39.06 \pm 11.11, \mathrm{p}=0.3$ ). An increase in $\mathrm{HF}$ values was also observed over the 15 minutes preceding the non-triggering SVEB (from $39.04 \pm 1.92$ to $47.04 \pm 2.48$ ) without statistical significance. In fact, the difference between the $\mathrm{HF}_{0-5}$ min preceding the triggering SBEV and the non-triggering SVEB was significant $(54.7 \pm 3.69$ vs $47.04 \pm 2.48, \mathrm{p}<0.001)$. Moreover, HF values during the 30 minutes preceding the triggering SVEB were significantly higher than during the 30 minutes before the non-triggering SVEB (Table 3 and Figure 3).

A progressive decrease in $\mathrm{LF} / \mathrm{HF}$ values was observed over the 30 minutes before the onset of vagal AF (from $0.85 \pm 0.1$ to $0.6 \pm 0.09$ ). There was no difference between the $\mathrm{LF} / \mathrm{HF}_{55-60}$ $\min$ and the $\mathrm{LF} / \mathrm{HF}_{24 \mathrm{~h}}(1.42 \pm 0.1$ vs $1.65 \pm 1.29, \mathrm{p}=0.49)$. A significant decrease in $\mathrm{LF} / \mathrm{HF}$ values was not observed over the 60 minutes preceding the non-triggering SVEB, with the lowest value measured during the $0-5 \mathrm{~min}$ period but with no statistically significant difference from the $\mathrm{LF} / \mathrm{HF}_{24 \mathrm{~h}}$ value $(0.97 \pm 0.08$ vs $1.65 \pm 1.29, \mathrm{p}=0.051)$. $\mathrm{LF} / \mathrm{HF}$ values during the 15 minutes preceding the triggering SVEB were significantly lower than during the same period before the non-triggering SVEB (Table 3 and Figure 3), with the difference between the $\mathrm{LF} / \mathrm{HF}_{0-5}$ min values being significant $(0.6 \pm 0.09$ vs $0.97 \pm 0.08, \mathrm{p}<0.001)$.

The values of the time-domain parameters analyzed before vagal onsets and the corresponding non- triggering SVEBs are also detailed in Table 4.

$H R V$ before triggering SVEBs and non-triggering SVEBs in adrenergic onsets 
A progressive increase in LF values was observed over the 25 minutes before the triggering SVEB (from $51.72 \pm 9.8$ to $67.51 \pm 5.24$ ); instead, this trend was not present before the nontriggering SVEB. $\mathrm{LF}_{0-5}$ min before the triggering $\mathrm{SVEB}$ was significantly higher than before the non- triggering SVEB $(67.51 \pm 5.24$ vs $52.04 \pm 1.99, \mathrm{p}<0.001)$. LF values during the 20 minutes before the triggering SVEB were significantly higher than before the non-triggering SVEB, except for the LF values during the 5-10 minutes period (Table 5 and Figure 3).

A significant decrease in HF values was observed over 10 minutes both before the onset of $\mathrm{AF}$ (from $38.26 \pm 9.52$ to $27.96 \pm 3.51$ ) and before the non-triggering SVEB (from $43.93 \pm$ 7.62 to $38.45 \pm 3.8) . \mathrm{HF}_{0-5} \min$ and the $\mathrm{HF}_{5-10 \text { min }}$ values preceding the onset of $\mathrm{AF}$ were significantly lower than the same values before the non-triggering SVEB $(27.96 \pm 3.51$ vs $38.45 \pm 3.8, \mathrm{p}<0.001 ; 25.94 \pm 4.39$ vs $31.93 \pm 3.16, \mathrm{p}<0.001)$. HF values from 45 to 20 minutes before the onset were significantly higher than before the non-triggering SVEB, whereas from 20 to 10 minutes before the ectopic beats considered there were no significant differences (Table 5 and Figure 3).

The LF/HF values increased over the 25 minutes preceding the onset of AF (from $1.24 \pm 0.38$ to $2.47 \pm 0.46$ ), with a statistically significant variation between the $\mathrm{LF} / \mathrm{HF}_{10-15}$ min and $\mathrm{LF} / \mathrm{HF}_{5-10}$ min components; this trend was absent before the non-triggering SVEB. No statistically significant difference was found between the $\mathrm{LF} / \mathrm{HF}_{0-5}$ min value before the nontriggering SVEB and the $\mathrm{LF} / \mathrm{HF}_{24 \mathrm{~h}}$ value $(1.37 \pm 0.15$ vs $1.21 \pm 0.94, \mathrm{p}=0.47)$. Furthermore, the $\mathrm{LF} / \mathrm{HF}$ values over the 10 minutes before the triggering SVEB were significantly higher than before the non-triggering SVEB (Table 5 and Figure 3), particularly between two $\mathrm{LF} / \mathrm{HF}_{0-5 \min }$ values $(2.47 \pm 0.46$ vs $1.37 \pm 0.15, \mathrm{p}<0.001)$.

The values of the time-domain parameters considered before adrenergic onsets and the corresponding non-triggering SVEBs are also reported in Table 6. 
Antiarrhythmic and betablocker therapy taken by patients did not influence the heart rate variability before either triggering SVEBs or non-triggering SVEBs (Figures 4 and 5).

\section{Discussion}

The role of the autonomic nervous system, one of three components of Coumelôs triangle, in the onset of AF has been studied for many years ${ }^{8,16}$ and has yet to be fully understood. Vagal stimulation has been proved to shorten the atrial refractory period ${ }^{17}$, thus facilitating the formation of intra-atrial reentry circuits. ${ }^{18,19}$ An increase in sympathetic activity, on the other hand, favors automaticity ${ }^{20}$ and delayed afterdepolarizations ${ }^{21}$. Various histologic studies ${ }^{22,23}$ have also shown that the autonomic innervation is not homogeneous across the atria, the nerve densities being the greatest in the left atrium within $5 \mathrm{~mm}$ of the pulmonary veins $\ddot{i}$ left atrium junction. This gradient of innervation causes the activity of the autonomic nervous system to be heterogeneous in the atria, thus favoring the formation of multiple wavelets and reentry circuits.

Variations of both sympathetic and vagal balance may be responsible for the onset of $\mathrm{AF}^{24}$ and can be studied with HRV analysis. Zimmermann et al. have observed an increase in vagal tone before the onset of ñoneò $\mathrm{AF}$ and this trend was later confirmed in patients with structural heart disease as well. ${ }^{25,26}$ Other studies have yet often evidenced the prevalence of the adrenergic tone during the minutes preceding the onset of $\mathrm{AF}^{27,28}$

In the present study, we observed both adrenergic (54.3\%) and vagal (45.7\%) patterns of AF onset, without any correlation between the type of episode and the time of occurrence, the gender and the treatment taken. In some patients both adrenergic and vagal onsets of AF took place at different times of day, as other reports have previously stated. ${ }^{28}$ 
HRV spectral analysis was performed in the hour preceding the onset of AF. We drew major conclusions from the frequency domain parameters, since they are more accurate in shortterm recordings and their physiological correlate is clearer than time-domain parameters. ${ }^{15} \mathrm{LF}$ is generally considered as a marker of the activity of the sympathetic nervous system, whereas HF is an indicator of the parasympathetic activity; the LF/HF ratio may be regarded as the expression of the relative activity of each branch of the autonomic nervous system. ${ }^{15}$ Although multiple studies ${ }^{25-28}$ have provided data about the activity of the autonomic nervous system before the episodes of AF, no studies, as far as we know, have yet compared the variations of $\mathrm{HRV}$ before the onset of $\mathrm{AF}$ with the variations of $\mathrm{HRV}$ that occur before an isolated non-triggering SVEB as premature as the triggering SVEB.

Vagal episodes of AF were preceded by a decrease in LF (NU) components starting 30 minutes before the triggering SVEB, with the lowest value reached in the 5 minutes before the onset of the arrhythmia. HF (NU) values linearly increased in the last 15 minutes preceding the triggering SVEB, even though a marked increase could be already noticed 25 minutes before the onset. LF/HF ratio decreased abruptly 25 minutes before the triggering SVEB and then contracted little until the onset of AF. This progressive increase in the parasympathetic tone before $\mathrm{AF}$ could not be noticed before the control non-triggering SVEB, which was rather preceded by chaotic fluctuations in the HRV parameters. The difference between HRV values before the triggering SVEB and the non-triggering SVEB proved statistically significant, thus indicating that the autonomic nervous system plays a major role in the onset of vagal AF. Transient trigger events, such as supraventricular extrasystoles, per se, may not be sufficient alone, in the same substrate environment, to initiate AF. One episode of AF was not triggered by a SVEB, suggesting that vagal hyperactivity alone may rarely be the sole responsible for the onset of AF. 
Adrenergic episodes of AF were preceded by a linear increase in LF (NU) values starting 25 minutes before the onset, suggesting a progressive increase in the sympathetic tone before the onset of this type of AF. On the other hand, HF (NU) components showed a linear and steep decrease until 5 minutes before the triggering SVEB and then modestly increased just before the onset of the arrhythmia; this little and yet observable increase in parasympathetic activity preceding even the onset of adrenergic AF agrees with previous reports from Zimmermann et al. ${ }^{14,25}$ according to whom every episode of AF is preceded by an increase in vagal tone. In the present study, however, the increase in HF values before the onset of ñadrenergic AFò occurred on a ground of overall sympathetic prevalence. ${ }^{29}$ A linear increase in LF/HF components took place between 25 and 5 minutes before the onset and remained unchanged in the last 5 minutes preceding the trigger event. A similar trend was not observed in the hour preceding the control non- triggering SVEB.

The better understanding of the role of the autonomous nervous system in the mechanisms of AF onset would allow us to develop specific therapeutic strategies, such as the autonomic balance modulation that has already been proven to be effective in reducing the $\mathrm{AF}$ occurrence30.

\section{Study limitations}

Only AF episodes lasting more than 30 seconds were analyzed and no conclusion can be taken for shorter episodes. The amount of onsets analyzed is relatively small due to the strict criteria of inclusion and exclusion that we used in order to have a precise HRV analysis. Exclusion of episodes with a higher burden of supraventricular ectopic beats may have caused the exclusion of a significant population; however, HRV analysis in the frequency domain is extremely altered if too many SVEBs are present during the recording period. ${ }^{15}$ 
A SVEB with the same CI and PC as the triggering oneô could not always be found, so some of the non-triggering SVEBs studied were similar but not identical to the triggering beats.

HRV analysis is then only an indirect marker of cardiac autonomic activity and the physiological correlates of some HRV parameters are not yet fully understood; the exact mechanisms underlying these parameters should therefore be interpreted with caution. All patients were on medication during the Holter monitoring, which may have altered the HRV analysis; no significant differences, however, were observed between the treatments taken by the two study groups.

\section{Conclusion}

The present study suggests that only SVEBs which occur during a phase of hyperactivity of one of the two branches of the autonomic nervous system are able to trigger episodes of AF. An increase in either adrenergic or vagal tone was observed before every onset of AF and the same patient sometimes showed both types of episodes at different times of day. These variations in the autonomic tone were observed in all kinds of patients, regardless of age, gender, heart disease and treatment taken. On the other hand, the same SVEBs, if preceded by random fluctuations of the autonomic tone, did not determine the onset of AF. This comes as further evidence that the activity of the autonomic nervous system plays a complex and yet most important role in the onset of AF.

\section{Author contributions}

Cristina Gallo: Concept/design, Statistics, Data analysis/interpretation, Drafting article, Critical revision of article 
Pier Paolo Bocchino: Concept/design, Data collection, Statistics, Data analysis/interpretation, Drafting article, Critical revision of article

Massimo Magnano: Concept/design, Data collection, Statistics, Data analysis/interpretation, Drafting article

Luca Gaido: Concept/design, Data collection, Statistics, Data analysis/interpretation

Domenica Zema: Data collection, Data analysis/interpretation, Drafting article

Alberto Battaglia: Concept/design, Statistics, Data analysis/interpretation, Drafting article, Critical revision of article

Matteo Anselmino: Concept/design, Data analysis/interpretation, Drafting article, Critical revision of article, Approval of article

Fiorenzo Gaita: Concept/design, Data interpretation, Critical revision of article, Approval of article

\section{References}

1. Chugh S, Blackshear Shen WK, Hammill SC, Gersh BJ: Epidemiology and Natural History of Atrial Fibrillation. J Am Coll Cardiol 2001; 37:371ї 378.

2. Coumel P: The management of clinical arrhythmias. An overview on invasive versus noninvasive electrophysiology. Eur Heart J 1987; 8:92-99.

3. Allessie M, Ausma J, Schotten U: Electrical, contractile and structural remodeling during atrial fibrillation. Cardiovasc Res 2002; 54:230-246.

4. Haissaguerre M, Jais P Shah DC, Takahashi A, Hocini M, Quiniou G, Garrigue S, Le Mouroux A, Le Métayer P, Clémenty J: Spontaneous initiation of atrial fibrillation by ectopic beats originating in the pulmonary veins. New Eng J Med 1998; 339:659-666. 
5. Bennett M, Pentecost B: The pattern of onset and spontaneous cessation of atrial fibrillation in man. Circulation 1970; 41:981-988.

6. Capucci A, Santarelli A, Boriani G, Magnani B: Atrial premature beats coupling interval determines lone paroxysmal atrial fibrillation onset. Int J Cardiol. 1992; 36:87-93.

7. Brian Olshansky: Interrelationships between the autonomic nervous system and atrial fibrillation. Prog Cardiovasc Dis. 2005; 48:57-78.

8. Coumel P, Attuel P, Lavallée J, Flammang D, Leclercq JF, Slama R: Syndrome dôrythmie auriculaire dôrigine vagale. Arch Mal Coeur. 1978; 71:645-656.

9. Coumel P: Paroxysmal atrial fibrillation: a disorder of autonomic tone? Eur Heart J 1994; 15:9ї 16.

10. Chen PS, Tan AY: Autonomic nerve activity and atrial fibrillation. Heart Rhythm 2007;4: S61ї S64.

11. Huang JL, Wen ZC, Lee WL, Chang MS, Chen SA: Changes of autonomic tone before the onset of paroxysmal atrial fibrillation. Int J Cardiol 1998; 66:275ï 283.

12. Perkiömäki J, Ukkola O, Kiviniemi A, Tulppo M, Ylitalo A, Kesäniemi YA, Huikuri H: Heart Rate Variability Findings as a Predictor of Atrial Fibrillation in Middle-Aged Population. J Cardiovasc Electrophysiol 2014; 25:719-724.

13. Lombardi F, Tarricone, Tundo F, Colombo F, Belletti S, Fiorentini C: Autonomic nervous system and paroxysmal atrial fibrillation: a study based on the analysis of RR interval changes before, during and after paroxysmal atrial fibrillation. Eur Heart J 2004; 25:1242ï 1248. 
14. Zimmermann M, Kalusche D: Fluctuation in Autonomic Tone is a Major Determinant of Sustained Atrial Arrhythmias in Patients with Focal Ectopy Originating from the Pulmonary Veins. J Cardiovasc Electrophysiol 2001; 12:285-91.

15. Task Force of the European Society of Cardiology and the North American Society of Pacing and Electrophysiology: Heart rate variability: standards of measurement, physiological interpretation, and clinical use. Circulation 1996; 93:1043ї 1065.

16. Coumel P, Attuel P, Leclercq JF, Friocourt P: Arythmies auriculaires dôrigine vagale ou catecholaminergique. Arch Mal Couer 1982; 4:373ї 381.

17. Coumel P: Autonomic influences in atrial tachyarrhythmias. J Cardiovasc Electrophysiol 1996; 7:999-1007.

18. Allessie MA, Bonke FIM, Schopman FJG: Circus movement in the rabbit atrial muscle as a mechanism of tachycardia: III. The ñleading circleò concept: a new model of circus movement of an anatomic obstacle. Crc Res 1976; 41:9-18.

19. Calò L, Pandozi C, Lamberti F, Riccardi R, Loricchio ML, Castro A, Gaita F, Santini M: Electrophysiology of atrial fibrillation: evolving insights. Ital Heart J 2000; 1:521-531.

20. DiFrancesco D: The role of the funny current in pacemaker activity. Circ Res 2010; 106:434-446.

21. Dobrev D, Voigt N, Wehrens XH: The ryanodine receptor channel as a molecular motif in atrial fibrillation: pathophysiological and therapeutic implications. Cardiovasc Res 2011; 89:734ї 743.

22. Tan AY, Li H, Wachsmann-Hogiu S, Chen LS, Chen PS, Fishbein MC: Autonomic innervation and segmental muscular disconnections at the human pulmonary vein-atrial 
junction: implications for catheter ablation of atrial-pulmonary vein junction. J Am Coll Cardiol 2006; 48:132ï 143.

23. Liu L, Nattel S: Differing sympathetic and vagal effects on atrial fibrillation in dogs: role of refractoriness heterogeneity. Am J Physiol 1997; 273:H805ї H816.

24. Zhou J, Scherlag BJ, Edwards J, Jackman WM, Lazzara R, Po SS: Gradients of atrial refractoriness and inducibility of atrial fibrillation due to stimulation of ganglionated plexi. $\mathbf{J}$ Cardiovasc Electrophysiol 2007; 18:83-90.

25. Bettoni M, Zimmermann M. Autonomic Tone Variations Before the Onset of Paroxysmal Atrial Fibrillation: Circulation 2002; 105:2753-2759.

26. Vincenti A, Brambilla R, Fumagalli MG, Merola R, Pedretti S: Onset mechanism of paroxysmal atrial fibrillation detected by ambulatory Holter monitoring. Europace 2006; 8:204-210.

27. Dimmer C, Tavernier R Gjorgov N, Van Nooten G, Clement DL, Jordaens L: Variations of autonomic tone preceding onset of atrial fibrillation after coronary artery bypass grafting. Am J Cardiol 1998; 82:22-25.

28. Fioranelli M, Piccoli M, Mileto GM, Sgreccia F, Azzolini P, Risa MP, Francardelli RL, Venturini E, Puglisi A: Analysis of heart rate variability five minutes before the onset of paroxysmal atrial fibrillation. PACE 1999; 22:743-749.

29. Porta A, Baselli G, Montano N, Gnecchi-Ruscone T, Lombardi F, Malliani A, Cerutti S: Non-linear dynamics in the beat-to-beat variability of sympathetic activity in decerebrate cats. Methods Inf Med 1994; 33(1):89-93. 
30. Linz D, Hohl M, Khoshkish S, Mahfoud F, Ukena C, Neuberger HR, Wirth K, Böhm MJ. Low-Level But Not High-Level Baroreceptor Stimulation Inhibits Atrial Fibrillation in a Pig Model of Sleep Apnea. J Cardiovasc Electrophysiol 2016;27(9):1086-92. 
Table 1. Clinical characteristics of the study population $(n=28)$

\begin{tabular}{|c|c|}
\hline Age (years) & $68,6 \pm 10,9$ \\
\hline Male/female & $19 / 9$ \\
\hline BMI $\left(\mathrm{kg} / \mathrm{m}^{2}\right)$ & $26,1 \pm 2,8$ \\
\hline Hypertension & $22(78,6 \%)$ \\
\hline Hyperthyroidism & $0(0,0 \%)$ \\
\hline Hypothyroidism ${ }^{*}$ & $2(7,1 \%)$ \\
\hline Ischemic heart disease & $9(32,1 \%)$ \\
\hline Hypertensive heart disease & $4(14,3 \%)$ \\
\hline Stroke/TIA & $1(3,6 \%)$ \\
\hline Diabetes & $5(17,9 \%)$ \\
\hline Heart failure & $0(0,0 \%)$ \\
\hline CHADS & $1,3 \pm 1,1$ \\
\hline $\mathrm{CHA}_{2} \mathrm{DS}_{2}-\mathrm{VASc}$ & $2,6 \pm 1,7$ \\
\hline HASBLED & $1,2 \pm 1,2$ \\
\hline Gastric disease & $6(21,4 \%)$ \\
\hline Previous ablation & $8(28,6 \%)$ \\
\hline \multicolumn{2}{|l|}{ Pharmacological therapy: } \\
\hline Amiodarone & $6(21,4 \%)$ \\
\hline Sotalol & $5(17,9 \%)$ \\
\hline Propafenone & $1(3,6 \%)$ \\
\hline Flecainide & $3(10,7 \%)$ \\
\hline Quinidine & $1(3,6 \%)$ \\
\hline Beta-Blocker & $18(64,3 \%)$ \\
\hline Digoxin & $4(14,3 \%)$ \\
\hline Calcium Channel Blocker & $7(25,0 \%)$ \\
\hline ACE-Inhibitor & $10(35,7 \%)$ \\
\hline Sartan & $5(17,9 \%)$ \\
\hline \multicolumn{2}{|l|}{ Echo parameters: } \\
\hline LA area $\left(\mathrm{cm}^{2}\right)$ & $23,9 \pm 4,9$ \\
\hline LA volume (ml) & $82,1 \pm 24,1$ \\
\hline $\operatorname{LVEF}(\%)$ & $61,5 \pm 5,1$ \\
\hline
\end{tabular}


Table 2. Vagal and adrenergic onsets $(n=35)$

\begin{tabular}{|c|c|c|c|}
\hline & Vagal onset $(n=16)$ & Andrenergic onset $(\mathrm{n}=19)$ & $P$-value \\
\hline Age (years) & $68,37 \pm 7$ & $69 \pm 12$ & 0,85 \\
\hline $\operatorname{BMI}\left(\mathrm{kg} / \mathrm{m}^{2}\right)$ & $26,7 \pm 3$ & $25,4 \pm 3$ & 0,21 \\
\hline Male/Female & $10 / 6$ & $12 / 7$ & 0,97 \\
\hline Hypertension & 13 & 15 & 0,86 \\
\hline Stroke/TIA & 0 & 2 & 0,54 \\
\hline Diabetes & 4 & 2 & 0,49 \\
\hline Gastric diseases & 3 & 5 & 0,9 \\
\hline Previous ablations & 5 & 3 & 0,49 \\
\hline Known heart diseases: & 9 & 8 & 0,62 \\
\hline Ischemic heart diseases & 7 & 5 & 0,47 \\
\hline Hypertensive heart diseases & 2 & 3 & 0,78 \\
\hline \multicolumn{4}{|l|}{ Pharmacological therapy: } \\
\hline Amiodarone & 3 & 3 & 0,82 \\
\hline Sotalol & 3 & 4 & 0,87 \\
\hline Propafenone & 1 & 0 & 0,93 \\
\hline Flecainide & 0 & 4 & 0,16 \\
\hline Quinidine & 0 & 1 & 0,35 \\
\hline Beta-Blocker & 9 & 14 & 0,47 \\
\hline Digoxin & 2 & 2 & 0,85 \\
\hline Calcium Channel Blocker & 7 & 2 & 0,06 \\
\hline ACE-Inhibitor & 6 & 7 & 0,97 \\
\hline Sartan & 2 & 3 & 0,78 \\
\hline \multicolumn{4}{|l|}{ Echo parameters: } \\
\hline LA area $\left(\mathrm{cm}^{2}\right)$ & $24 \pm 6$ & $23,09 \pm 4$ & 0,69 \\
\hline LA volume (ml) & $86,73 \pm 28$ & $82,82 \pm 21$ & 0,71 \\
\hline LVEF $(\%)$ & $59,8 \pm 6$ & $62,13 \pm 5$ & 0,26 \\
\hline Coupling interval & $521 \pm 123$ & $494 \pm 70$ & 0,42 \\
\hline Preceding PP cycle & $962 \pm 263$ & $919 \pm 155$ & 0,52 \\
\hline Prematurity index & $0,52 \pm 0,2$ & $0,55 \pm 0,1$ & 0,57 \\
\hline $\mathrm{LF} / \mathrm{HF}_{24 \mathrm{~h}}$ & $1,6 \pm 2$ & $1,2 \pm 1$ & 0,45 \\
\hline Standard deviation of the NN interval ${ }_{24 \mathrm{~h}}$ & $155,24 \pm 64,79$ & $140,95 \pm 61,51$ & 0,51 \\
\hline Standard deviation of the NN interval ${ }_{0-5 \text { min }}$ & $54,71 \pm 4,12$ & $73,61 \pm 14,09$ & $<0,001^{*}$ \\
\hline Duration of the AF episode (s) & $5821 \pm 12800$ & $5938 \pm 7763$ & 0,97 \\
\hline
\end{tabular}

$\mathrm{HF}=$ high frequency; $\mathrm{LF}=$ low frequency;

$* P$-value $<0,05$ 
Table 3. Changes in Frequency-Domain HRV parameters before the AF vagal onset and the corresponding non-triggering SVEB

\begin{tabular}{|c|c|c|c|c|c|c|c|c|c|c|c|c|c|c|c|}
\hline & \multicolumn{2}{|c|}{ LF } & \multirow[b]{2}{*}{$\begin{array}{c}P \\
\text { value }\end{array}$} & \multicolumn{2}{|c|}{ HF } & \multirow[b]{2}{*}{$\begin{array}{c}P \\
\text { value }\end{array}$} & \multicolumn{2}{|c|}{ LF/HF } & \multicolumn{3}{|c|}{ VLF } & \multirow[b]{2}{*}{$\begin{array}{c}P \\
\text { value }\end{array}$} & \multicolumn{2}{|c|}{ VHF } & \multirow[b]{2}{*}{$\begin{array}{c}P \\
\text { value }\end{array}$} \\
\hline & TSVEB & NTSVEB & & TSVEB & NTSVEB & & TSVEB & NTSVEB & $\begin{array}{c}P \\
\text { value }\end{array}$ & TSVEB & NTSVEB & & TSVEB & NTSVEB & \\
\hline $0-5$ & $\begin{array}{c}32,73^{\mathrm{a}}= \\
3,54\end{array}$ & $\begin{array}{l}45,25 \mathrm{abc} \\
\pm 2,08\end{array}$ & 0,000 & $\begin{array}{c}54,70^{e}= \\
3,69\end{array}$ & $\begin{array}{c}47,04^{\mathrm{cd}}= \\
2,48\end{array}$ & 0,000 & $\begin{array}{c}0,60^{\mathrm{a}}= \\
0,09\end{array}$ & $\begin{array}{c}0,97^{\mathrm{a}} \pm \\
0,08\end{array}$ & 0,000 & $\begin{array}{c}51,73^{\mathrm{a}}= \\
2,16\end{array}$ & $\begin{array}{c}54,40^{\mathrm{ab}}= \\
6,29\end{array}$ & 0,059 & $\begin{array}{l}12,66^{\mathrm{cd}} \\
=4,12\end{array}$ & $\begin{array}{c}7,79^{\mathrm{ab}}= \\
2,17\end{array}$ & 0,001 \\
\hline $5-10$ & $\begin{array}{c}41,45^{b} \pm \\
3,27\end{array}$ & $\begin{array}{l}45,21^{\mathrm{abc}} \\
=2,45\end{array}$ & 0,001 & $\begin{array}{l}51,60^{\text {de }} \\
=1,56\end{array}$ & $\begin{array}{c}46,39^{\mathrm{cd}} \pm \\
2,96\end{array}$ & 0,000 & $\begin{array}{c}0,80^{\mathrm{ab}} \pm \\
0,08\end{array}$ & $\begin{array}{c}0,98^{\mathrm{a}} \pm \\
0,08\end{array}$ & 0,000 & $\begin{array}{c}62,04^{\mathrm{a}} \pm \\
4,96\end{array}$ & $\begin{array}{c}48,83^{\mathrm{ab}}= \\
10,81\end{array}$ & 0,002 & $\begin{array}{c}7,06^{\mathrm{ab}} \pm \\
2,97\end{array}$ & $\begin{array}{c}8,42^{\mathrm{abc}} \pm \\
4,05\end{array}$ & 0,186 \\
\hline $\begin{array}{l}10- \\
15\end{array}$ & $\begin{array}{c}41,38^{\circ} \pm \\
2,60\end{array}$ & $\begin{array}{c}48,62^{\text {ed }} \pm \\
2,31\end{array}$ & 0,000 & $\begin{array}{l}49,13^{\text {cd }} \\
\pm 3,69\end{array}$ & $\begin{array}{c}39,04^{\mathrm{a}} \pm \\
1,92\end{array}$ & 0,000 & $\begin{array}{c}0,85^{\mathrm{ab}} \pm \\
0,10\end{array}$ & $\begin{array}{c}1,25^{\mathrm{ab}} \pm \\
0,11\end{array}$ & 0,000 & $\begin{array}{c}33,91^{\mathrm{a}} \pm \\
2,98\end{array}$ & $\begin{array}{c}43,90^{\mathrm{ab}}= \\
2,87\end{array}$ & 0,000 & $\begin{array}{c}9,53^{\text {bed }} \pm \\
3,67\end{array}$ & $\begin{array}{c}12,39 \text { de } \\
2,23\end{array}$ & 0,005 \\
\hline $\begin{array}{l}15- \\
20\end{array}$ & $\begin{array}{c}40,81^{b} \pm \\
2,30\end{array}$ & $\begin{array}{c}40,54^{\mathrm{a}} \pm \\
1,67\end{array}$ & 0,680 & $\begin{array}{l}50,37^{\text {de }} \\
\pm 2,18\end{array}$ & $\begin{array}{c}41,87^{\mathrm{abc}} \\
\pm 1,87\end{array}$ & 0,000 & $\begin{array}{c}0,81^{\mathrm{ab}} \pm \\
0,06\end{array}$ & $\begin{array}{c}0,99^{\mathrm{a}} \pm \\
0,39\end{array}$ & 0,091 & $\begin{array}{c}38,40^{\mathrm{a}} \pm \\
2,96\end{array}$ & $\begin{array}{c}36,71^{\mathrm{a}} \pm \\
1,93\end{array}$ & 0,120 & $\begin{array}{c}8,94^{b c}= \\
3,30\end{array}$ & $\begin{array}{c}16,23^{\mathrm{e}} \pm \\
3,89\end{array}$ & 0,000 \\
\hline $\begin{array}{l}20- \\
25\end{array}$ & $\begin{array}{l}39,09^{\mathrm{ab}} \\
\pm 4,18\end{array}$ & $\begin{array}{c}49,47^{\mathrm{cd}}= \\
2,64\end{array}$ & 0,000 & $\begin{array}{l}51,00 \text { de } \\
\pm 4,36\end{array}$ & $\begin{array}{c}45,8^{b c d}= \\
4,03\end{array}$ & 0,000 & $\begin{array}{c}0,78^{\mathrm{ab}}= \\
0,17\end{array}$ & $\begin{array}{c}1,09^{\mathrm{a}}= \\
0,13\end{array}$ & 0,000 & $\begin{array}{c}39,98^{\mathrm{a}}= \\
25,45\end{array}$ & $\begin{array}{c}47,51^{\mathrm{ab}}= \\
5,01\end{array}$ & 0,313 & $\begin{array}{c}9,90^{b c d}= \\
2,61\end{array}$ & $\begin{array}{c}4,84^{3}= \\
2,87\end{array}$ & 0,000 \\
\hline $\begin{array}{l}25- \\
30\end{array}$ & $\begin{array}{c}43,52^{b}= \\
1,79\end{array}$ & $\begin{array}{c}43,73^{\mathrm{abc}} \\
\pm 4,19\end{array}$ & 0,848 & $\begin{array}{c}44,01^{b c} \\
\pm 3,40\end{array}$ & $\begin{array}{c}49,71^{\mathrm{d}}= \\
3,75\end{array}$ & 0,000 & $\begin{array}{c}1,38^{c}= \\
0,32\end{array}$ & $\begin{array}{c}0,89^{\mathrm{a}}= \\
0,14\end{array}$ & 0,000 & $\begin{array}{c}44,69^{\mathrm{a}}= \\
48,76\end{array}$ & $\begin{array}{c}63,03^{\mathrm{abc}} \\
\pm 7,73\end{array}$ & 0,180 & $\begin{array}{l}12,49^{\mathrm{cd}} \\
=3,35\end{array}$ & $\begin{array}{c}6,59^{3}= \\
3,71\end{array}$ & 0,000 \\
\hline $\begin{array}{l}40- \\
45\end{array}$ & $\begin{array}{c}52,22^{\mathrm{c}}= \\
3,14\end{array}$ & $\begin{array}{c}41,85^{\mathrm{ab}}= \\
2,87\end{array}$ & 0,000 & $\begin{array}{c}43,75^{b}= \\
2,78\end{array}$ & $\begin{array}{c}46,88^{\mathrm{cd}}= \\
5,23\end{array}$ & 0,045 & $\begin{array}{c}1,20^{b c}= \\
0,13\end{array}$ & $\begin{array}{c}2,45^{\mathrm{c}}= \\
0,29\end{array}$ & 0,000 & $\begin{array}{l}75,7^{3}= \\
214,92\end{array}$ & $\begin{array}{c}88,67^{c}= \\
27,90\end{array}$ & 0,810 & $\begin{array}{c}4,07^{\mathrm{a}}= \\
2,55\end{array}$ & $\begin{array}{c}11,3^{b c d}= \\
4,31\end{array}$ & 0,000 \\
\hline $\begin{array}{l}55- \\
60\end{array}$ & $\begin{array}{c}50,81^{c} \pm \\
1,67\end{array}$ & $\begin{array}{c}47,3^{\text {bed }} \pm \\
2,21\end{array}$ & 0,000 & $\begin{array}{c}36,00^{\mathrm{a}} \pm \\
2,30\end{array}$ & $\begin{array}{c}40,66^{\mathrm{ab}} \pm \\
3,17\end{array}$ & 0,000 & $\begin{array}{c}1,42^{c} \pm \\
0,10\end{array}$ & $\begin{array}{c}1,17^{\mathrm{ab}} \pm \\
0,13\end{array}$ & 0,000 & $\begin{array}{c}53,16^{\mathrm{a}} \pm \\
3,96\end{array}$ & $\begin{array}{c}49,84^{\mathrm{ab}} \pm \\
2,03\end{array}$ & 0,003 & $\begin{array}{c}13,23^{\mathrm{d}}= \\
2,95\end{array}$ & $\begin{array}{c}12,13^{\mathrm{cd}} \pm \\
2,98\end{array}$ & 0,305 \\
\hline $24 \mathrm{~h}$ & $\begin{array}{c}52,37^{\mathrm{c}} \pm \\
15,14\end{array}$ & $\begin{array}{c}52,37^{\mathrm{d}}= \\
15,14\end{array}$ & & $\begin{array}{l}39,06^{\mathrm{ab}} \\
\pm 11,11\end{array}$ & $\begin{array}{c}39,06^{\mathrm{a}}= \\
11,11\end{array}$ & & $\begin{array}{c}1,65^{\mathrm{c}}= \\
1,29\end{array}$ & $\begin{array}{c}1,65^{b}= \\
1,29\end{array}$ & & $\begin{array}{c}67,92^{\mathrm{a}}= \\
76,39\end{array}$ & $\begin{array}{c}67,92^{b c}= \\
76,39\end{array}$ & & $\begin{array}{c}8,01^{b}= \\
4,48\end{array}$ & $\begin{array}{c}8,01^{\mathrm{ab}}= \\
4,48\end{array}$ & \\
\hline
\end{tabular}

Values are expressed as mean $=\mathrm{SD}$. Analysis of variance (ANOVA) was used to compare data obtained at different time intervals. 0-5, 5-10, 10-15, 15-20, 20-25, 25-30, 40$45,55-60=$ time interval (in minutes) preceding the triggering SVEB (TSVEB) and the non-triggering (NTSVEB); $24 \mathrm{~h}=24$-hour period of recording; a, b.c, d,e homogeneous subgroups according to the Bonferroni correction ( $P$ value $<0,05$ was considered as significant for post-hoc analysis). Other abbreviations as defined in the text.| 
Table 4. Changes in Time-Domain HRV Parameters Before the Vagal Onset of AF and the Corresponding non-triggering SVEB

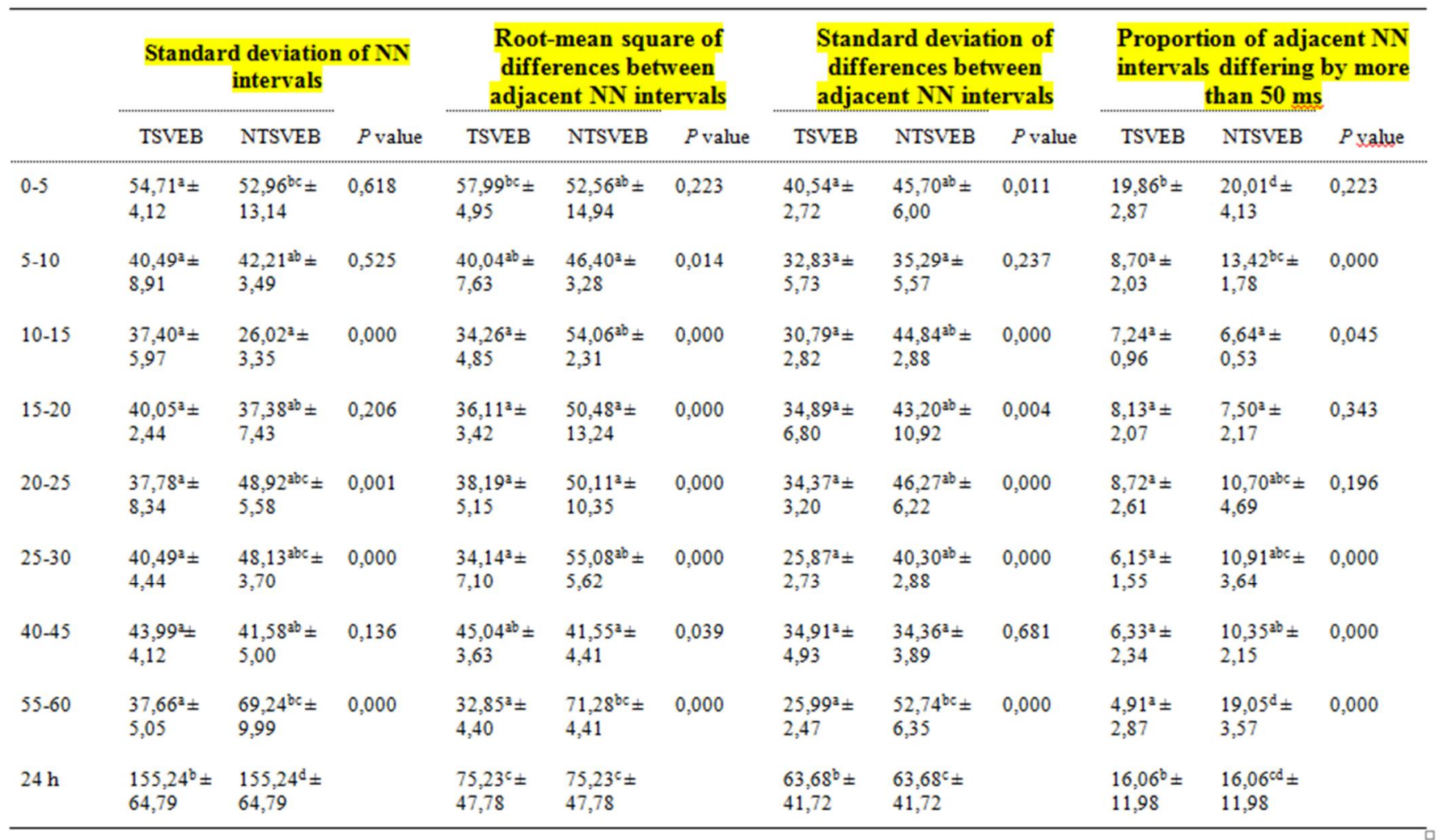

Values are expressed as mean $\pm \mathrm{SD}$. Analysis of variance (ANOVA) was used to compare data obtained at different time intervals. Abbreviations as in Table 3. 
Table 5. Changes in Frequency-Domain HRV Parameters Before the Adrenergic Onset of AF and the Corresponding non triggering SVEB

\begin{tabular}{|c|c|c|c|c|c|c|c|c|c|c|c|c|c|c|c|}
\hline & \multicolumn{2}{|r|}{$\mathbf{L F}$} & \multirow[b]{2}{*}{$\begin{array}{c}P \\
\text { value }\end{array}$} & \multicolumn{2}{|r|}{$\mathbf{H F}$} & \multirow[b]{2}{*}{$\begin{array}{c}P \\
\text { value }\end{array}$} & \multicolumn{2}{|r|}{ LF/HF } & \multirow[b]{2}{*}{$\begin{array}{c}P \\
\text { value }\end{array}$} & \multicolumn{2}{|r|}{ VLF } & \multirow[b]{2}{*}{$\begin{array}{c}P \\
\text { value }\end{array}$} & \multicolumn{2}{|r|}{ VHF } & \multirow[b]{2}{*}{$\begin{array}{c}P \\
\text { yalue }\end{array}$} \\
\hline & TSVEB & NTSVEB & & TSVEB & NTSVEB & & TSVEB & NTSVEB & & TSVEB & NTSVEB & & TSVEB & NTSVEB & \\
\hline $0-5$ & $\begin{array}{l}67,51^{\mathrm{d}} \\
\pm 5,24\end{array}$ & $\begin{array}{l}52,04^{a b c} \\
\pm 1,99\end{array}$ & 0,000 & $\begin{array}{l}27,96^{\mathrm{ab}} \\
\pm 3,51\end{array}$ & $\begin{array}{l}38,45^{b c}= \\
3,80\end{array}$ & 0,000 & $\begin{array}{l}2,47^{b}= \\
0,46\end{array}$ & $\begin{array}{l}1,37^{\mathrm{a}}= \\
0,15\end{array}$ & 0,000 & $\begin{array}{l}44,74^{\mathrm{a}} \\
\pm 2,73\end{array}$ & $\begin{array}{l}37,01^{\mathrm{a}}= \\
2,53\end{array}$ & 0,000 & $\begin{array}{l}4,58^{\mathrm{a}}= \\
3,31\end{array}$ & $\begin{array}{l}9,59^{\mathrm{a}}= \\
4,11\end{array}$ & 0,001 \\
\hline $5-10$ & $\begin{array}{l}62,35^{\mathrm{cd}} \\
\pm 5,16\end{array}$ & $\begin{array}{l}63,03^{d}= \\
3,09\end{array}$ & 0,556 & $\begin{array}{l}25,94^{\mathrm{a}} \\
\pm 4,39\end{array}$ & $\begin{array}{l}31,93^{a b}= \\
3,16\end{array}$ & 0,000 & $\begin{array}{l}2,48^{b}= \\
0,49\end{array}$ & $\begin{array}{l}1,99^{\mathrm{a}}= \\
0,24\end{array}$ & 0,001 & $\begin{array}{l}60,25^{\mathrm{ab}} \\
\pm 3,10\end{array}$ & $\begin{array}{l}53,53^{\mathrm{a}}= \\
2,91\end{array}$ & 0,000 & $\begin{array}{l}11,81^{\circ} \\
\pm 6,10\end{array}$ & $\begin{array}{l}5,01^{\mathrm{a}}= \\
3,82\end{array}$ & 0,000 \\
\hline $\begin{array}{l}10- \\
15\end{array}$ & $\begin{array}{l}57,68^{b c} \\
\pm 10,41\end{array}$ & $\begin{array}{l}50,68^{a b}= \\
5,63\end{array}$ & 0,019 & $\begin{array}{l}38,26^{\mathrm{cd}} \\
\pm 9,52\end{array}$ & $\begin{array}{l}43,93^{c}= \\
7,62\end{array}$ & 0,054 & $\begin{array}{l}1,66^{\mathrm{a}}= \\
0,70\end{array}$ & $\begin{array}{l}1,20^{3}= \\
0,32\end{array}$ & 0,18 & $\begin{array}{l}57,58^{\mathrm{ab}} \\
\pm 14,00\end{array}$ & $\begin{array}{l}45,52^{\mathrm{a}}= \\
9,23\end{array}$ & 0,001 & $\begin{array}{l}4,16^{\mathrm{a}}= \\
4,14\end{array}$ & $\begin{array}{l}5,40^{3}= \\
3,39\end{array}$ & 0,322 \\
\hline $\begin{array}{l}15- \\
20\end{array}$ & $\begin{array}{l}55,24^{b c} \\
=9,66\end{array}$ & $\begin{array}{l}47,35^{\mathrm{a}} \pm \\
7,48\end{array}$ & 0,010 & $\begin{array}{l}40,7 \mathrm{~g}^{\mathrm{cd}} \\
=9,32\end{array}$ & $\begin{array}{l}42,65^{c} \pm \\
7,82\end{array}$ & 0,443 & $\begin{array}{l}1,49^{a} \pm \\
0,65\end{array}$ & $\begin{array}{l}1,18^{\mathrm{a}} \pm \\
0,43\end{array}$ & 0,060 & $\begin{array}{l}74,00^{b} \\
=13,32\end{array}$ & $\begin{array}{l}37,71^{\mathrm{a}} \pm \\
9,09\end{array}$ & 0,000 & $\begin{array}{l}4,00^{\mathrm{a}} \pm \\
2,76\end{array}$ & $\begin{array}{l}10,01^{\mathrm{a}} \pm \\
4,06\end{array}$ & 0,000 \\
\hline $\begin{array}{l}20- \\
25\end{array}$ & $\begin{array}{l}51,72^{\mathrm{ab}} \\
\pm 9,80\end{array}$ & $\begin{array}{l}57,8^{b c d}= \\
12,14\end{array}$ & 0,067 & $\begin{array}{l}44,10^{d} \\
\pm 8,10\end{array}$ & $\begin{array}{l}34,40^{\mathrm{ab}}= \\
6,92\end{array}$ & 0,000 & $\begin{array}{l}1,24^{3}= \\
0,38\end{array}$ & $\begin{array}{l}1,80^{\mathrm{a}}= \\
0,64\end{array}$ & 0,002 & $\begin{array}{l}59,45^{\text {ab }} \\
\pm 9,14\end{array}$ & $\begin{array}{l}35,56^{\mathrm{a}}= \\
7,21\end{array}$ & 0,000 & $\begin{array}{l}4,23^{\mathrm{a}}= \\
3,55\end{array}$ & $\begin{array}{l}7,88^{3}= \\
6,42\end{array}$ & 0,033 \\
\hline $\begin{array}{l}25- \\
30\end{array}$ & $\begin{array}{l}52,47^{a b} \\
=4,03\end{array}$ & $\begin{array}{l}60,50^{\mathrm{cd}}= \\
4,05\end{array}$ & 0,000 & $\begin{array}{l}35,8^{c}= \\
3,47\end{array}$ & $\begin{array}{l}33,99^{\mathrm{ab}}= \\
2,76\end{array}$ & 0,027 & $\begin{array}{l}1,48^{a} \pm \\
0,22\end{array}$ & $\begin{array}{l}1,80^{\mathrm{a}}= \\
0,25\end{array}$ & 0,000 & $\begin{array}{l}49,09^{\mathrm{a}} \\
\pm 4,48\end{array}$ & $\begin{array}{l}51,37^{\mathrm{a}}= \\
5,68\end{array}$ & 0,243 & $\begin{array}{l}11,76^{\circ} \\
=4,10\end{array}$ & $\begin{array}{l}11,18^{\mathrm{a}} \pm \\
23,37\end{array}$ & 0,916 \\
\hline $\begin{array}{l}40- \\
45\end{array}$ & $\begin{array}{l}52,58^{\mathrm{ab}} \\
=5,13\end{array}$ & $\begin{array}{l}63,38^{d}= \\
5,70\end{array}$ & 0,000 & $\begin{array}{l}40,21^{\text {cd }} \\
=3,07\end{array}$ & $\begin{array}{l}31,28^{3}= \\
4,28\end{array}$ & 0,000 & $\begin{array}{l}1,32^{3}= \\
0,20\end{array}$ & $\begin{array}{l}2,08^{a}= \\
0,41\end{array}$ & 0,000 & $\begin{array}{l}46,76^{3} \\
\pm 6,41\end{array}$ & $\begin{array}{l}57,39^{3}= \\
8,80\end{array}$ & 0,000 & $\begin{array}{l}7,26^{\mathrm{ab}}= \\
4,50\end{array}$ & $\begin{array}{l}5,36^{3}= \\
3,94\end{array}$ & 0,119 \\
\hline $\begin{array}{l}55- \\
60\end{array}$ & $\begin{array}{l}55,40^{b c} \\
=4,95\end{array}$ & $\begin{array}{l}58,5^{\text {bcd }}= \\
9,15\end{array}$ & 0,217 & $\begin{array}{l}33,78^{b c} \\
\pm 5,82\end{array}$ & $\begin{array}{l}32,44^{a b}= \\
6,61\end{array}$ & 0,530 & $\begin{array}{l}2,76^{b}= \\
1,24\end{array}$ & $\begin{array}{l}3,48^{b}= \\
2,70\end{array}$ & 0,321 & $\begin{array}{l}52,67^{\mathrm{ab}} \\
\pm 4,54\end{array}$ & $\begin{array}{l}48,49^{\mathrm{a}}= \\
8,85\end{array}$ & 0,089 & $\begin{array}{l}10,89^{b} \\
=4,85\end{array}$ & $\begin{array}{l}9,18^{a}= \\
4,82\end{array}$ & 0,252 \\
\hline $24 \mathrm{~h}$ & $\begin{array}{l}43,83^{\mathbf{3}} \\
=17,49\end{array}$ & $\begin{array}{l}43,83^{3}= \\
17,49\end{array}$ & & $\begin{array}{l}44,49^{d} \\
\pm 11,38\end{array}$ & $\begin{array}{l}44,49^{c}= \\
11,38\end{array}$ & & $\begin{array}{l}1,21^{\mathrm{a}}= \\
0,94\end{array}$ & $\begin{array}{l}1,21^{a}= \\
0,94\end{array}$ & & $\begin{array}{l}50,54^{3} \\
\pm 64,52\end{array}$ & $\begin{array}{l}50,54^{a}= \\
64,52\end{array}$ & & $\begin{array}{l}11,68^{b} \\
\pm 6,94\end{array}$ & $\begin{array}{l}11,68^{\mathrm{a}}= \\
6,94\end{array}$ & \\
\hline
\end{tabular}

Values are expressed as mean $=\mathrm{SD}$. Analysis of variance (ANOVA) was used to compare data obtained at different time intervals. Abbreviations as in Table 3. 
Table 6. Changes in Time-Domain HRV Parameters Before the Adrenergic Onset of AF and the Corresponding non-triggering SVEB

\begin{tabular}{|c|c|c|c|c|c|c|c|c|c|c|c|c|}
\hline & \multicolumn{3}{|c|}{$\begin{array}{c}\text { Standard deviation of NN } \\
\text { intervals }\end{array}$} & \multicolumn{3}{|c|}{$\begin{array}{l}\text { Root-mean square of } \\
\text { differences between } \\
\text { adjacent NN intervals }\end{array}$} & \multicolumn{3}{|c|}{$\begin{array}{l}\text { Standard deviation of } \\
\text { differences between } \\
\text { adjacent } N N \text { intervals }\end{array}$} & \multicolumn{3}{|c|}{$\begin{array}{l}\text { Proportion of adjacent NN } \\
\text { intervals differing by more } \\
\text { than } 50 \mathrm{~ms}\end{array}$} \\
\hline & TSVEB & NTSVEB & $P$ value & TSVEB & NTSVEB & $P$ value & TSVEB & NTSVEB & $P$ value & TSVEB & NTSVEB & $P$ yalue \\
\hline $0-5$ & $\begin{array}{l}73,61^{b}= \\
14,09\end{array}$ & $\begin{array}{l}75,01^{b}= \\
3,65\end{array}$ & 0,655 & $\begin{array}{l}58,91^{\mathrm{c}}= \\
8,90\end{array}$ & $\begin{array}{l}76,07^{b}= \\
5,21\end{array}$ & 0,000 & $\begin{array}{l}48,35^{d}= \\
4,39\end{array}$ & $\begin{array}{l}57,92^{b}= \\
5,74\end{array}$ & 0,000 & $\begin{array}{l}15,32^{\mathrm{dd}}= \\
2,54\end{array}$ & $\begin{array}{l}13,38^{\mathrm{cd}}= \\
2,48\end{array}$ & 0,038 \\
\hline $5-10$ & $\begin{array}{l}59,32^{c b}= \\
4,14\end{array}$ & $\begin{array}{l}53,34^{3}= \\
8,00\end{array}$ & 0,014 & $\begin{array}{l}53,65^{b c}= \\
7,91\end{array}$ & $\begin{array}{l}50,55^{\mathrm{a}}= \\
9,02\end{array}$ & 0,287 & $\begin{array}{l}45,39^{\mathrm{cd}}= \\
2,63\end{array}$ & $\begin{array}{l}34,61^{3}= \\
9,28\end{array}$ & 0,000 & $\begin{array}{l}12,78^{b c d}= \\
2,13\end{array}$ & $\begin{array}{l}10,66^{\mathrm{abc}}= \\
2,82\end{array}$ & 0,026 \\
\hline $10-15$ & $\begin{array}{l}50,15^{\mathrm{a}}= \\
9,75\end{array}$ & $\begin{array}{l}51,47^{\mathrm{a}}= \\
9,53\end{array}$ & 0,677 & $\begin{array}{l}39,46^{\mathrm{a}}= \\
10,79\end{array}$ & $\begin{array}{l}47,50^{\mathrm{a}}= \\
8,27\end{array}$ & 0,004 & $\begin{array}{l}37,48^{a b c}= \\
8,64\end{array}$ & $\begin{array}{l}42,63^{\mathrm{a}}= \\
8,14\end{array}$ & 0,030 & $\begin{array}{l}9,35^{a b}= \\
4,43\end{array}$ & $\begin{array}{l}7,91^{\mathrm{a}}= \\
3,23\end{array}$ & 0,166 \\
\hline $15-20$ & $\begin{array}{l}61,85^{\mathrm{ab}}= \\
10,54\end{array}$ & $\begin{array}{l}55,65^{a b} \pm \\
10,13\end{array}$ & 0,046 & $\begin{array}{l}50,52^{\mathrm{abc}}= \\
6,25\end{array}$ & $\begin{array}{l}49,35^{\mathrm{a}}= \\
6,72\end{array}$ & 0,601 & $\begin{array}{l}40,16^{\mathrm{ab} e d} \\
\pm 5,54\end{array}$ & $\begin{array}{l}40,27^{\mathrm{a}}= \\
6,21\end{array}$ & 0,935 & $\begin{array}{l}10,61^{a b c}= \\
4,54\end{array}$ & $\begin{array}{l}7,42^{\mathrm{a}}= \\
3,50\end{array}$ & 0,003 \\
\hline $20-25$ & $\begin{array}{l}63,19^{a b}= \\
14,13\end{array}$ & $\begin{array}{l}51,80^{3}= \\
10,44\end{array}$ & 0,001 & $\begin{array}{l}48,34^{a b c}= \\
13,60\end{array}$ & $\begin{array}{l}46,84^{3}= \\
10,96\end{array}$ & 0,675 & $\begin{array}{l}41,40^{b c d}= \\
4,92\end{array}$ & $\begin{array}{l}43,35^{a}= \\
10,51\end{array}$ & 0,437 & $\begin{array}{l}11,22^{\mathrm{abc}}= \\
6,68\end{array}$ & $\begin{array}{l}6,98^{a}= \\
2,70\end{array}$ & 0,010 \\
\hline $25-30$ & $\begin{array}{l}47,85^{a}= \\
4,87\end{array}$ & $\begin{array}{l}57,53^{\mathrm{ab}}= \\
6,84\end{array}$ & 0,000 & $\begin{array}{l}41,26^{\mathrm{ab}}= \\
4,94\end{array}$ & $\begin{array}{l}47,31^{3}= \\
2,65\end{array}$ & 0,000 & $\begin{array}{l}30,32^{3}= \\
5,18\end{array}$ & $\begin{array}{l}40,62^{\mathrm{a}}= \\
3,11\end{array}$ & 0,000 & $\begin{array}{l}8,13^{\mathrm{ab}}= \\
2,09\end{array}$ & $\begin{array}{l}7,03^{\mathrm{a}}= \\
1,36\end{array}$ & 0,091 \\
\hline $40-45$ & $\begin{array}{l}51,65^{\mathrm{ab}}= \\
8,94\end{array}$ & $\begin{array}{l}51,58^{a}= \\
6,41\end{array}$ & 0,974 & $\begin{array}{l}37,95^{\mathrm{a}}= \\
5,92\end{array}$ & $\begin{array}{l}43,92^{\mathrm{a}}= \\
4,92\end{array}$ & 0,003 & $\begin{array}{l}32,94^{a b}= \\
5,54\end{array}$ & $\begin{array}{l}34,28^{a}= \\
3,33\end{array}$ & 0,342 & $\begin{array}{l}7,25^{a}= \\
4,16\end{array}$ & $\begin{array}{l}8,76^{\mathrm{ab}}= \\
2,47\end{array}$ & 0,180 \\
\hline $55-60$ & $\begin{array}{l}55,50^{\mathrm{ab}}= \\
8,55\end{array}$ & $\begin{array}{l}59,62^{\mathrm{ab}}= \\
7,48\end{array}$ & 0,093 & $\begin{array}{l}47,40^{a b c}= \\
6,69\end{array}$ & $\begin{array}{l}44,75^{\mathrm{a}}= \\
8,43\end{array}$ & 0,369 & $\begin{array}{l}39,70^{\text {abcd }} \\
=6,83\end{array}$ & $\begin{array}{l}34,30^{\mathrm{a}}= \\
7,98\end{array}$ & 0,039 & $\begin{array}{l}8,68^{\mathrm{ab}}= \\
3,50\end{array}$ & $\begin{array}{l}13,26^{\text {bcd }}= \\
5,99\end{array}$ & 0,006 \\
\hline $24 \mathrm{~h}$ & $\begin{array}{l}190,45^{c}= \\
61,51\end{array}$ & $\begin{array}{l}190,45^{\mathrm{c}}= \\
61,51\end{array}$ & & $\begin{array}{l}82,44^{d}= \\
30,74\end{array}$ & $\begin{array}{l}82,44^{b}= \\
30,74\end{array}$ & & $\begin{array}{l}71,17^{e}= \\
27,32\end{array}$ & $\begin{array}{l}71,17^{\mathrm{c}}= \\
27,32\end{array}$ & & $\begin{array}{l}16,99^{d}= \\
9,51\end{array}$ & $\begin{array}{l}16,99^{d}= \\
9,51\end{array}$ & \\
\hline
\end{tabular}

Values are expressed as mean $=\mathrm{SD}$. Analysis of variance (ANOVA) was used to compare data obtained at different time intervals. Abbreviations as in Table 3. 


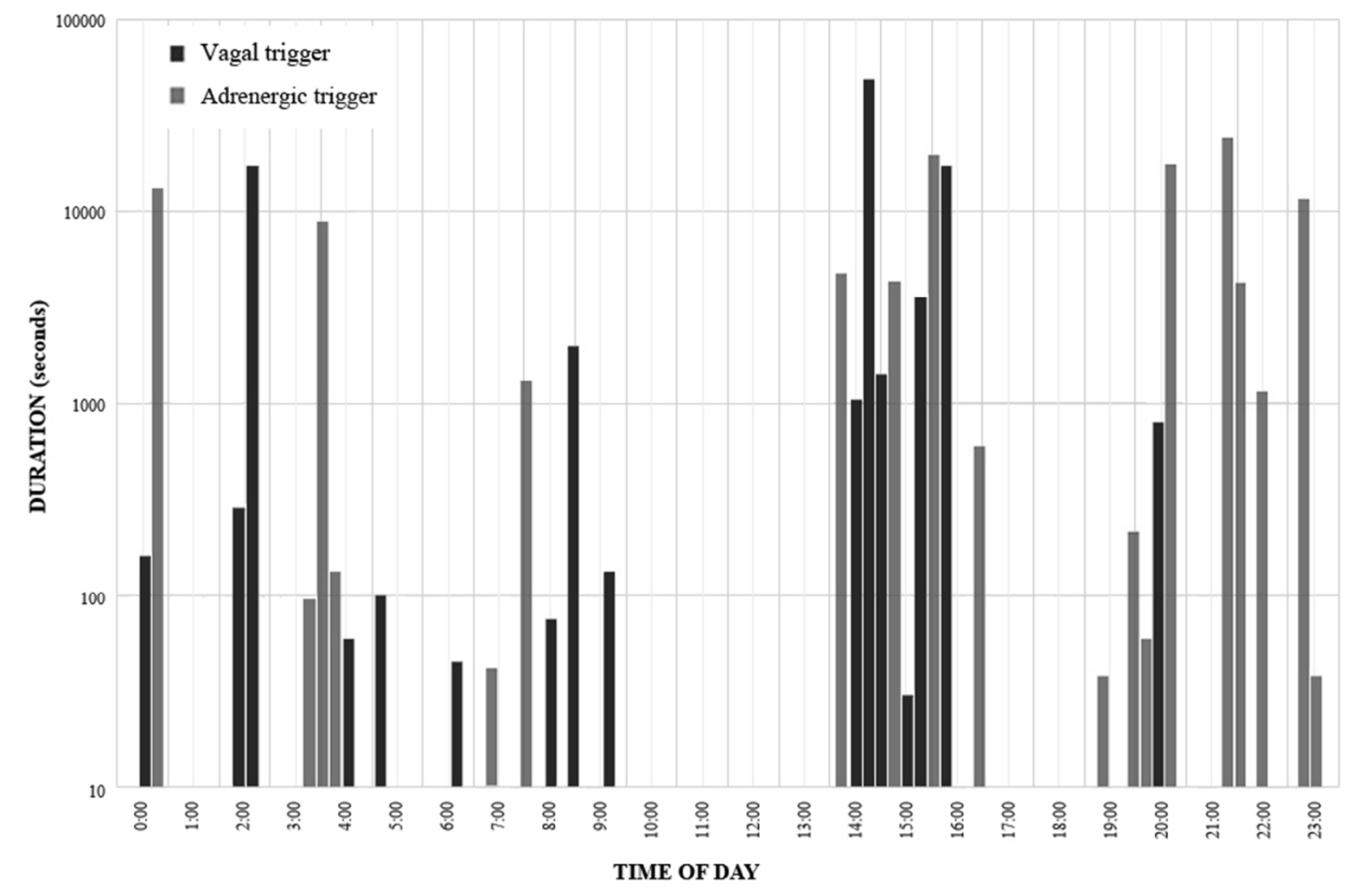

Figure 1. Duration of the AF episodes in relation to the time of onset. 

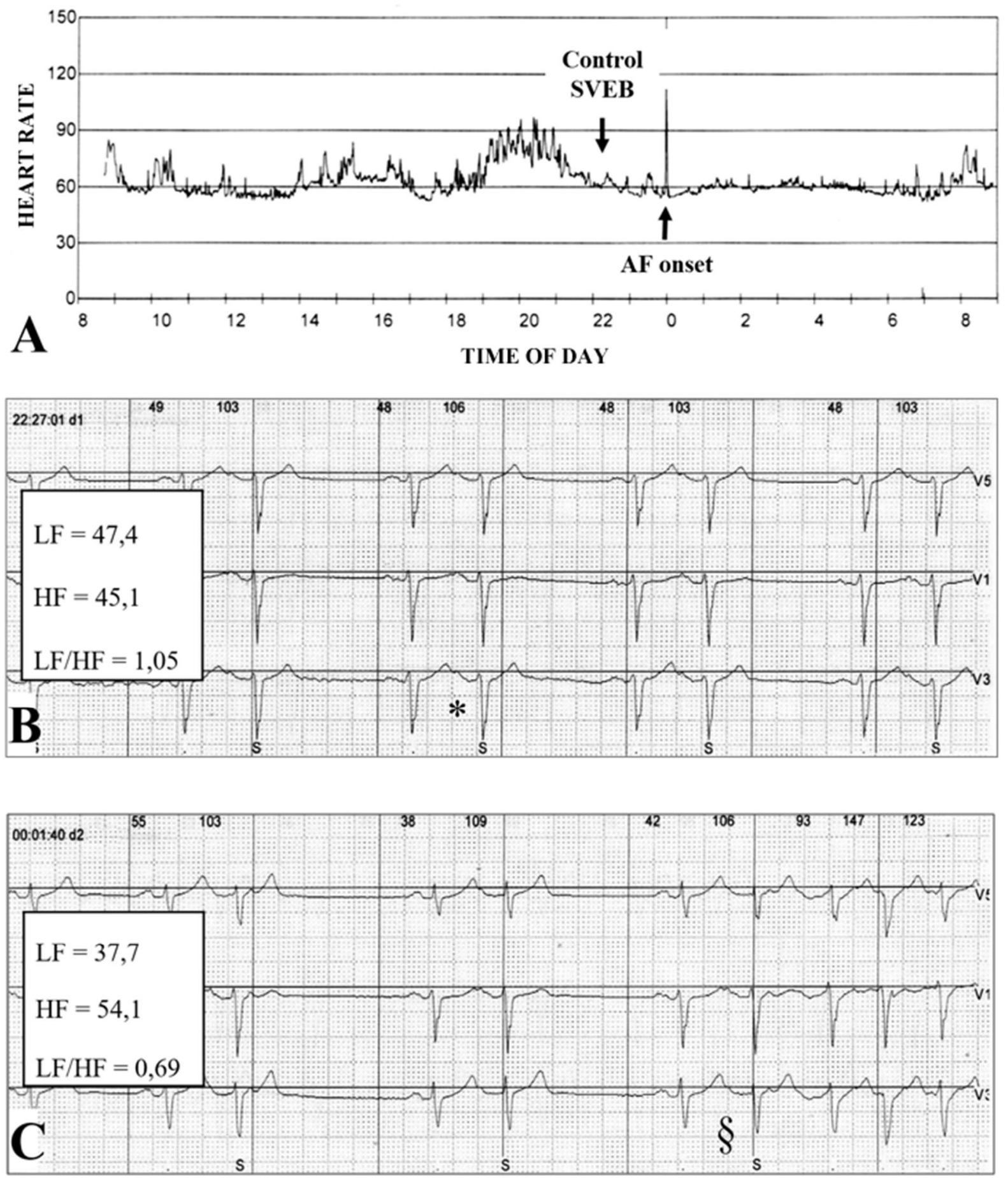

Figure 2. An example of autonomic nervous system activity before a triggering SVEB and its control non-triggering SVEB. (A) Heart rate trend. (B) ECG showing the control nontriggering SVEB (asterisk) and HRV parameters calculated over the 5 minutes preceding the control SVEB. (C) ECG showing the triggering SVEB (§) and HRV parameters calculated over the 5 minutes preceding AF onset. 
LF Changes - Group A

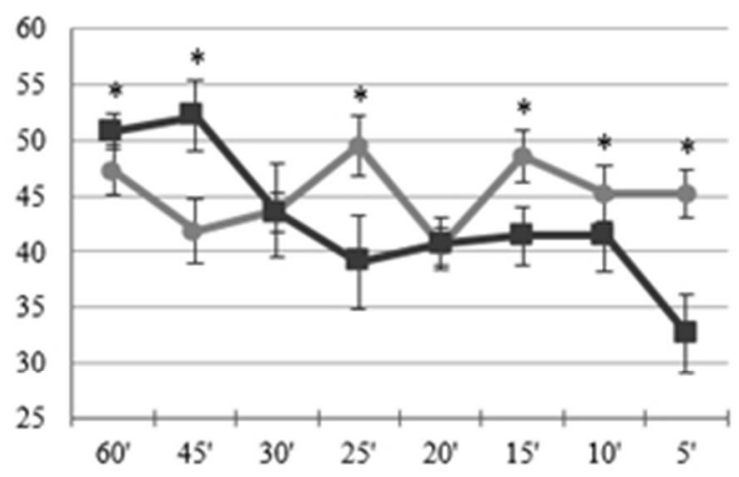

HF Changes - Group A

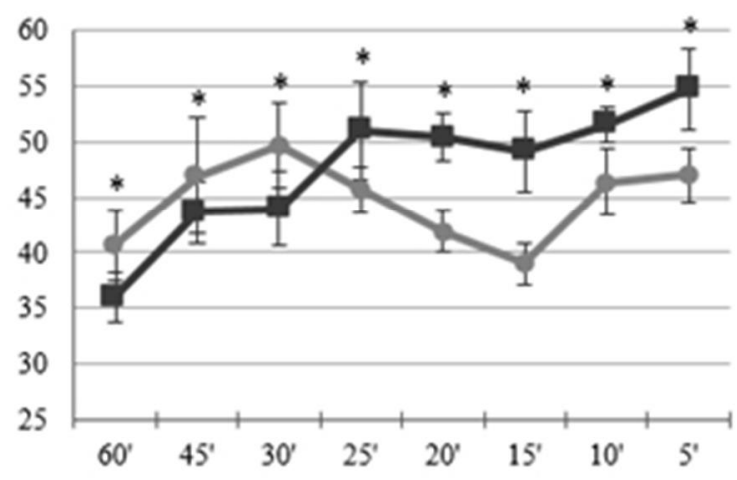

LF/HF Changes - Group A

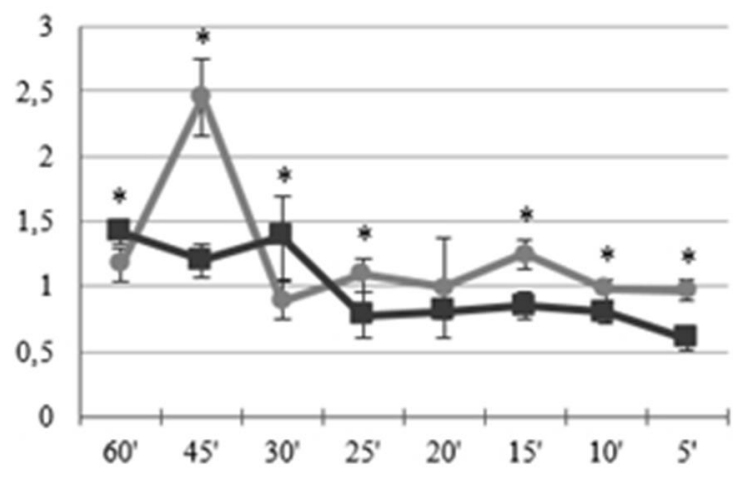

LF Changes - Group B

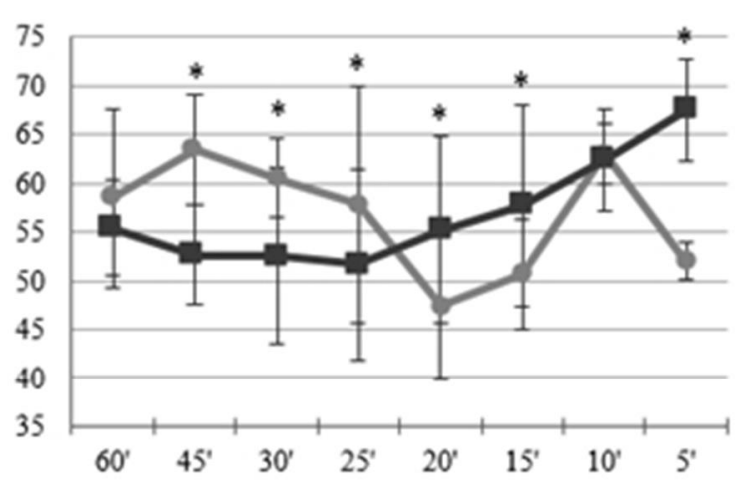

HF Changes - Group B

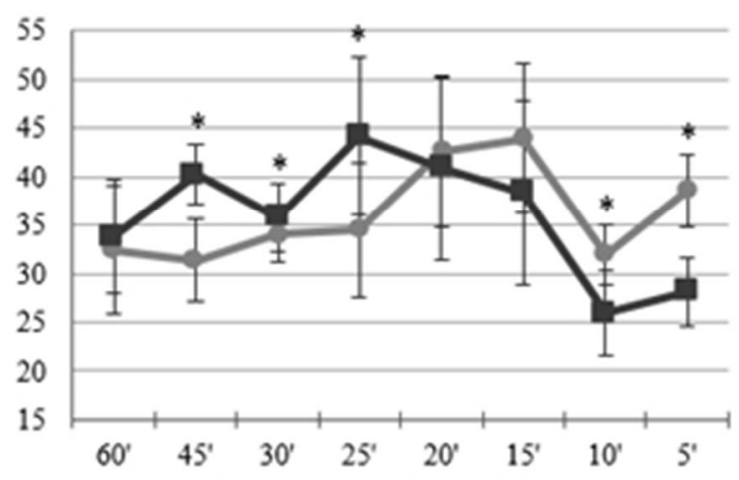

LF/HF Changes - Group B

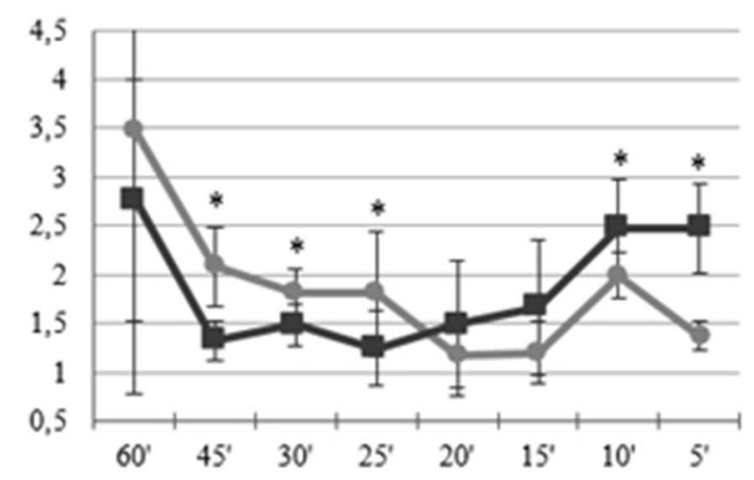

Figure 2. Dynamic changes in HRV parameters before the onset of AF (dark gray) and before the corresponding control non-triggering SVEB (light gray). The asterisks represent significant differences $(P$-value $<0,05)$ between each parameter and its corresponding control value. 
LF Changes - AF onset

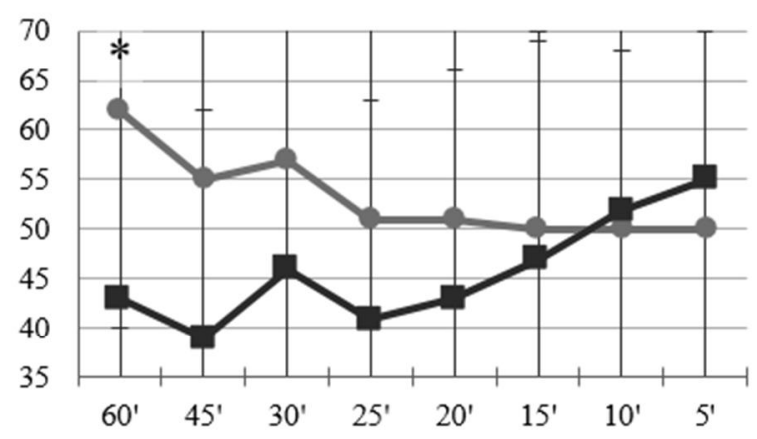

HF Changes - AF onset

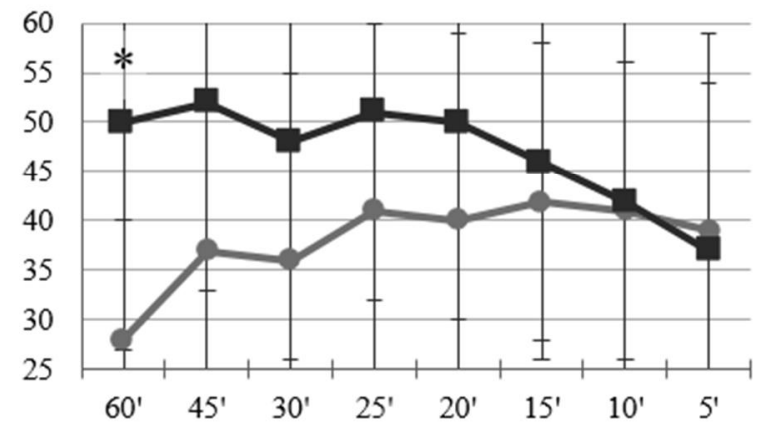

LF/HF Changes - AF onset

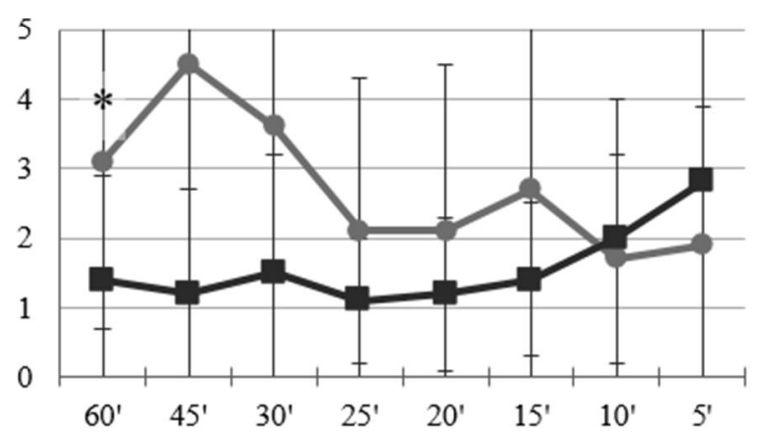

LF Changes - Control SVEB

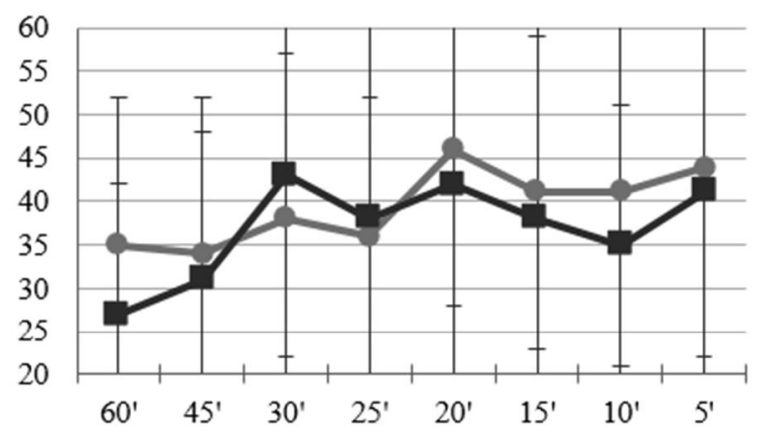

HF Changes - Control SVEB

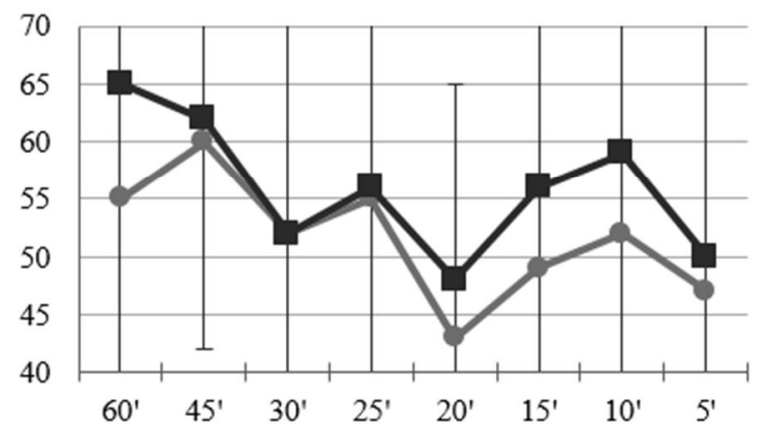

LF/HF Changes - Control SVEB

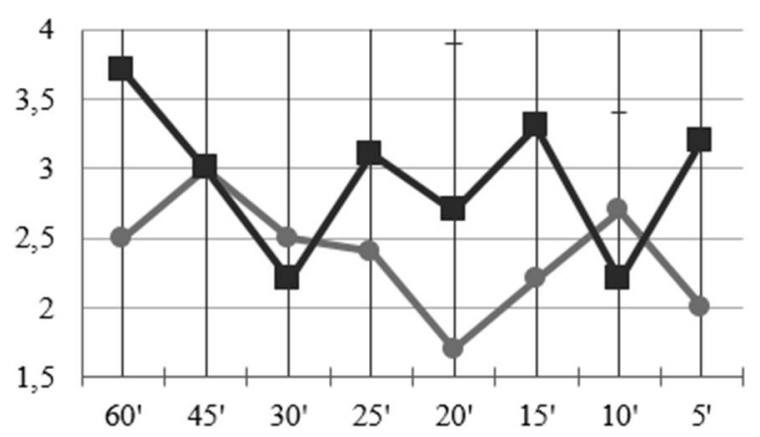

Figure 4. Dynamic changes in HRV parameters before AF onsets and the corresponding nontriggering SVEBs in patients taking anti-arrhythmic drugs (dark gray) or not (light gray). The asterisks represent significant differences $(P$-value $<0,05)$ between each parameter and its corresponding control value. 
LF Changes - AF onset

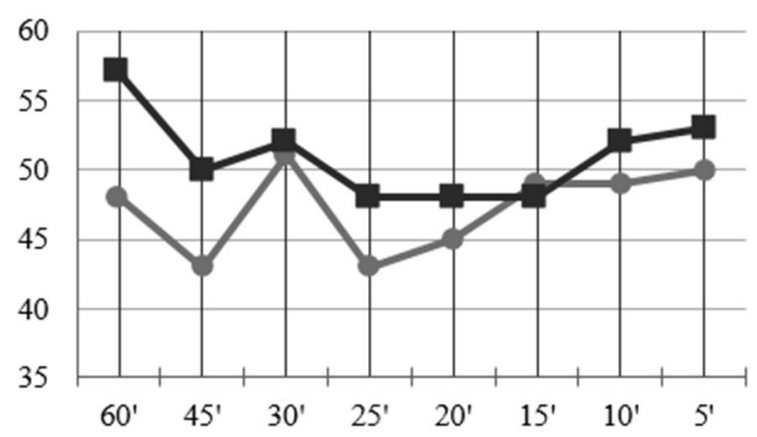

HF Changes - AF onset

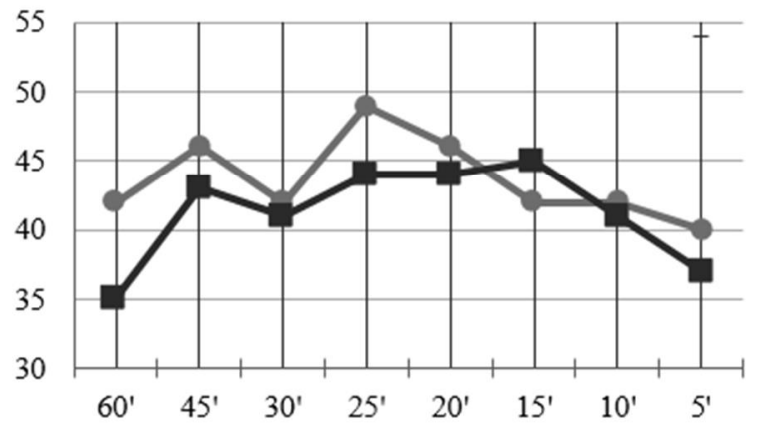

LF/HF Changes - AF onset

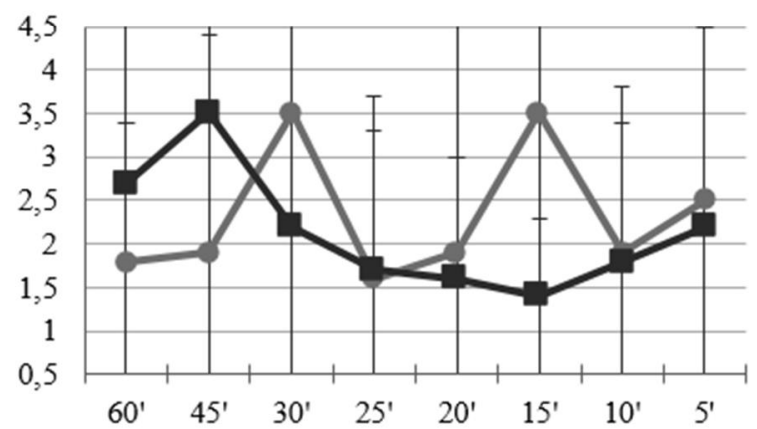

LF Changes - Control SVEB

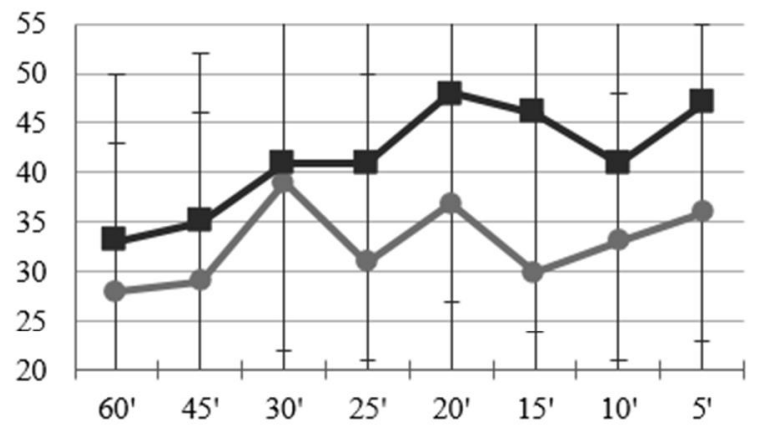

HF Changes - Control SVEB

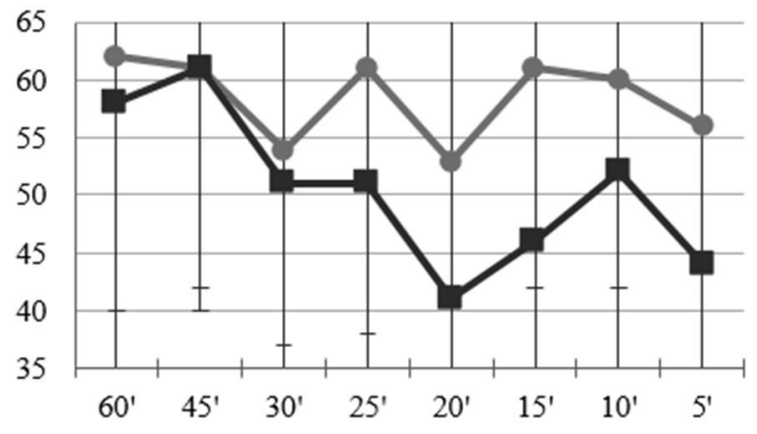

LF/HF Changes - Control SVEB

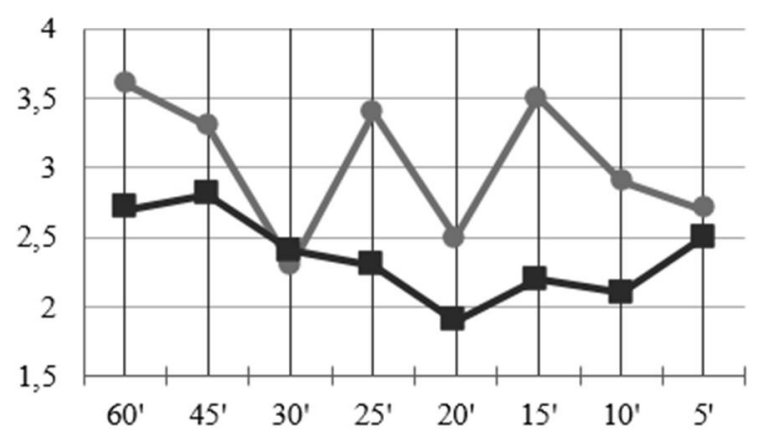

Figure 5. Dynamic changes in HRV parameters before AF onsets and the corresponding nontriggering SVEBs in patients taking beta-blockers (dark gray) or not (light gray). 